
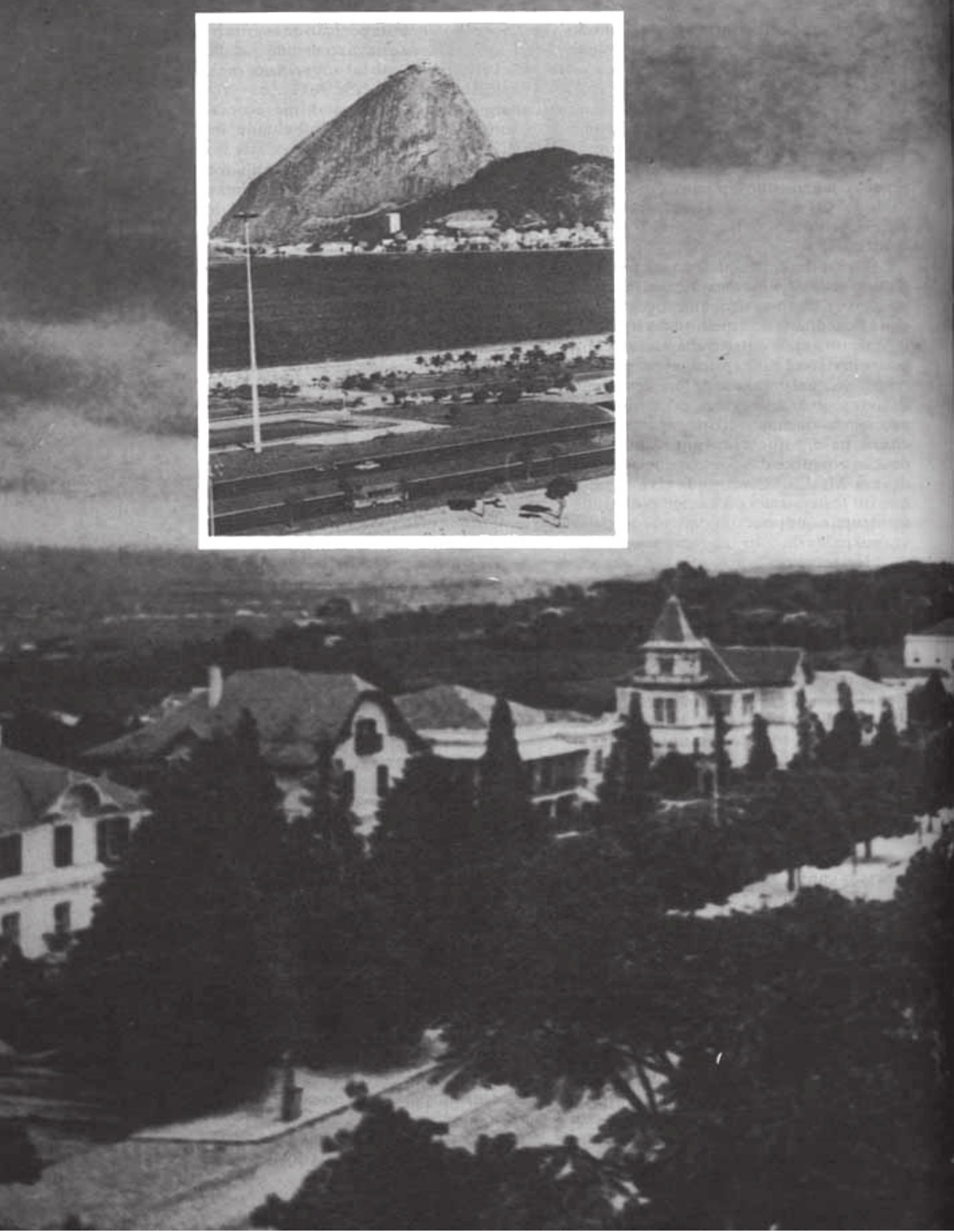
MARIA IRENE SZMRECSANYI

\section{Rio e São Paulo: raízes da substituição da metrópole naciona}

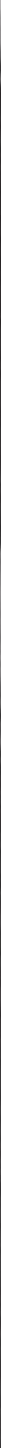




\section{O PROBLEMA}

Dentro do processo de urbanização na América Latina, já caracterizado na historiografia como sendo, em cada país, altamente concentrado $\mathrm{cm}$ uma cidade primaz(Hardoy, Scobie), a metropolizaçãodo Brasil mostra feições próprias. Isto não só pela pujança macrorregional das capitais estaduais, constituídas hoje $\mathrm{em}$ áreas metropolitanasmas, principalmente, pela substituiçăo da metrópole nacional, ocorrida em poucas décadas deste século.

Este tipo de fenômeno, além de raro empiricamente, aparece comode baixa probabilidade teórica quandose aceita que, sob a regência do mercado, o acúmulode vantagens localizacionais tende a auto-alimentar-se até a saturação das economias de escala. Desse pontode vista, é surpreendente que o Rio de Janeiro, tendo sediado localmente ogovernoda colônia e dovice-reino, havendo se tornado capital do Império, da Primeira República e do Estado Novo, sendoa cidade mais populosa co principal porto dopaís, batendo comoseu coração político, funcionando como seu centro comercial, financeiroe industrial, abrigandoo cerne de sua intelligentsia e liderando a modernizaçảo de seus costumes $\mathrm{e}$ instituiçōes, tenha, no auge do seu brilho urbano e dentro de uma estrutura econômica de mercado, perdido sua posição privilegiada $\mathrm{em}$ favor de SảoPaulo.

Tanto mais porque esta última cidade, apesar de sua posiçấo estratégica como nó de caminhos para o interior da colônia (Prado Jr.), levou dois séculos com porte de vila e mais de três para surgir como a segunda do país. Por outro lado, localizando-se a distância relativamente curta do Riocsediando ogoverno em nível apenas provincial, veio a prosperar concorrendo com ele nas mesmas atividades cconômicas: basicamente a indústria manufatureira c o controle da produção do café, através de mobilizaçảo de capitais e terras, organização do crédito, recrutamentoe distribuiçăoda mão-de-obra, implantação c exploração do sistema de transportes ferroviários, c, com Santos, comercialização internacional. Aoque se somam a exploraçấo de serviços públicos e a especulaçẩo imobiliária urbana.

A expansảo demográfica das duas cidadesé espetacular desde oséculo XIX, em cuja década de 30 o Riojá tinha perto de 140 mil habitantes enquanto Sảo Paulonảoatingia 22 mil, e em cujotranscorrer a primeira cidade manteve-se de 6 a 9 vezes maior do que a segunda. Dessa forma, em 1890, uma ultrapassara meio milhảo de moradores enquantoa outra se acercava dos $65 \mathrm{mil}$. No entanto, durante oúltimo quartel doséculo SãoPaulocresceu mais depressa e cada vez mais intensamente, a pontode expandir-se 3,7 vezes entre $1890 \mathrm{e} 1900$, quandoalcançou 240 mil habitantes, enquantoo Rio, sem chegar a dobrar, passou a constituir um colosso para a época, com mais de $800 \mathrm{mil}$ almas. Portanto, na virada deste séculoSảo Paulo equivalia a $1 / 3$ do Rio. Em 1920 cla tinha a metade da sua população (aproximadamente 580 mil vs. 1,160 milhão). Em 1940 subiu para $75 \%$ (1,3 vs. 1,7 milhảo). Em 1950 chegou a $92 \%(2,20$ vs. $2,38 \mathrm{mi}$ lhỏes). E em 1960 ultrapassou o Rio enquanto município(3,8vs. 3,3 milhöes), mas nãoenquantoárea metropolitana, categoria censitária recém-criada ( 4 vs. 4,6 milhōes). Só em 1970Sảo Paulo tornou-se mais populosa do que o Rio em ambas as classifi. caçöes (5,9vs. 4,3 milhões os municípiose 7,7 vs. 6,8 as respectivas áreas metropolita. nas), e vem mantendo superioridade atéo presente.

Por esses números pode-se perceber que a troca da metrópole nacional se armou desde o início deste século, o que torna o conjunto de suas primeiras décadas e últimasdoséculoanterior períodoclássicopara o entendimento do fenômeno. Por outro lado, a cvolução descrita também mostra que essa mudança nada ou pouco teve a ver com Brasília ou a grande indústria automobilística introduzida a partir de 1956, quese fizeram quando São Paulo demogra. ficamente já se igualara ao Rio e economicamente já se consolidara enquantosede de emprecndimentos hegemônicos em todoo país.

Como e por que a substituiçāo da metrópole brasileira se tornou possível constituem as questöes examinadas neste trabalho. Dopontode vista de São Paulo, elas se mostraram de particular interesse para al. guns autores, entre os quais Singer deve set destacado. Do ponto de vista do Rio, esses problemas mereceram alguma atençáo de Lobo e Leopoldi. A compreensảo das circunstâncias e processos dentro dos quais ocorreu a competiçẩo entre os dois núcleos pode avançar através de análises feitas a partir de novosângulos ou integrandodiferentesperspectivas.

Retoma-se aqui o tema privilegiando uma aproximação sociopolítica da cvolu. 
ção urbana descrita, cujas bases são reconhecidamente cconômicas. A partir dela formulam-se hipóteses reciprocamente complementares sobre as origens desse processo e procuram-se alguns de seus fundamentos empíricos na fase cafecira de 18501930 , istoé, da extinçäodo tráfico negreiro à crise da economia de exportaçāo.

\section{AS H IPÓT ES ES: OPÇÖES DE IN VESTIMENTO}

As questōes selecionadas são por si só próprias e relevantes enquanto problemas urbanos e regionais. Elas têm também implicaçōes maiores devido às influências metropolitanas exercidas sobre todoopaís, quer por uma, quer por outra, quer mesmo pelas duas cidades em conjunto, desde a segunda metade do século passado. Seus papéis têm sido essenciais durante o processo, que se mostra longoe difícil de constituição de uma economia nacional diversificada, integrada e auto-orientanda.

De acordo com a cscola da Cepal de pensamento econômico que floresceu durante as décadas de 1950 c 1960, a América
Latina superaria scu passado colonial através da industrialização. Ocepalino Furtado, acompanhandooutros historiadoresbem conhecidos como Prado Jr. e Simonsen, aponta o abandono da escravidāo em favor dotrabalho livre como a mudança institucional decisiva para a industrializaçāo e o desenvolvimento cconômico sustentado. Ainda que a industrialização nāotenha atendido muitas esperanças de bem-estar para as massas e de autonomia nacional, $\mathrm{e}$ ainda que a teoria cepalina tenha nos últimos anos sofrido cerradas críticas, a primazia que atribuiu ao trabalho livre para o adventoda modernidade no Brasil é ponto de concordância para economistas, historiadores, sociólogos ou politicólogos.

Tanto as cidades como as províncias do Rio de Janeiro e de São Paulo se beneficiaram da escravidão até 1888 , seu término pela lei e na prática. Eambas as cidades viram crescer sua indústria particularmente a partir de 1890, trabalhada, portanto, pela mâo-de-obra livre. O avanço demográfico e econômico de Sâo Paulo ocorreu, entretanto, predominantemente no período do trabalho assalariado, enquanto o do Rio começara antes, sob o escravismo, perden-

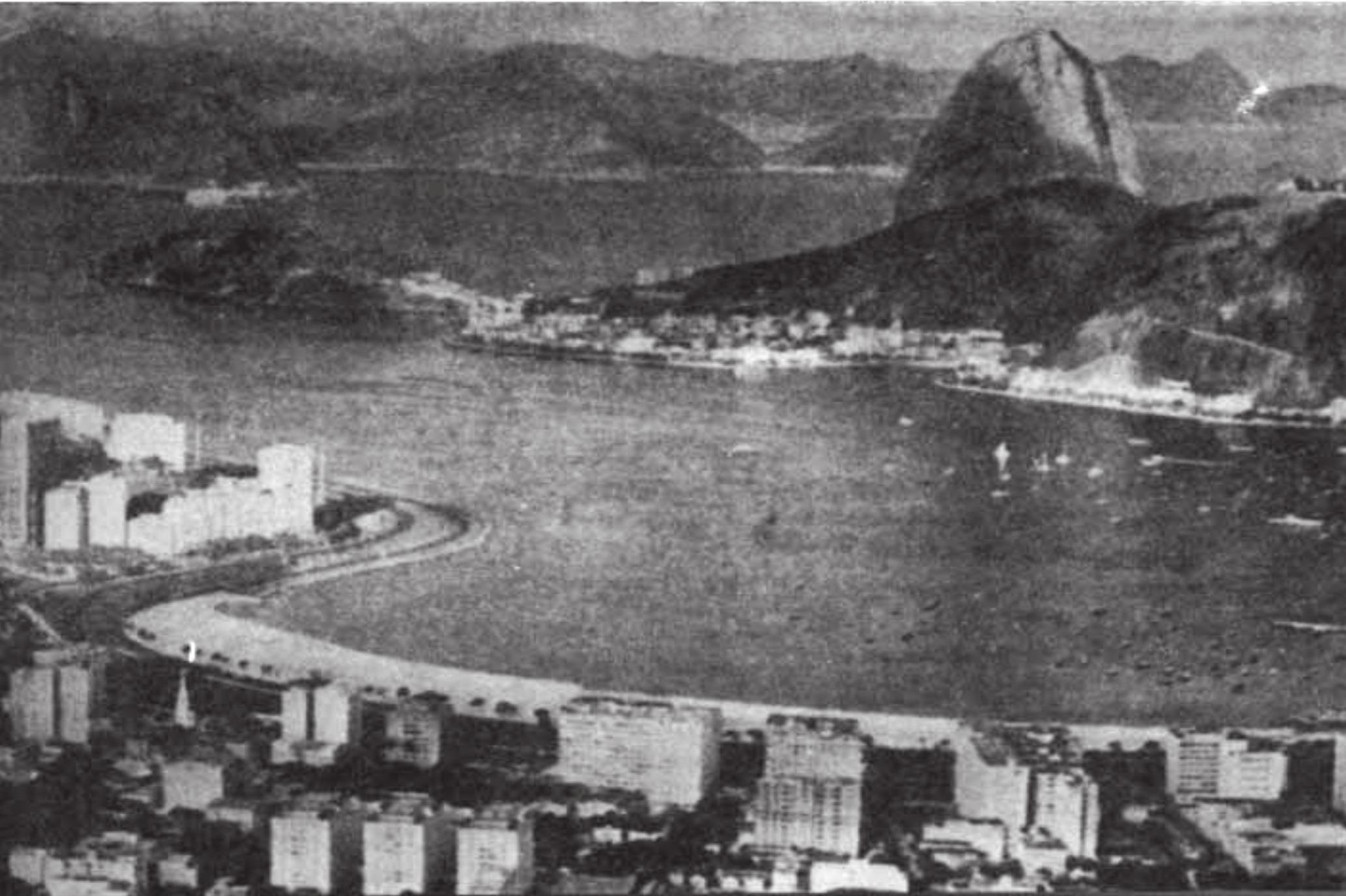


do ímpeto gradualmente após a abolição. Esta é uma diferença essencial, com repercussōes prolongadas para as transformaçōes urbanas, que aqui será usada como pressuposto da argumentaçâo desenvolvida.

Escrevendo na década de 1960, Singer atribuiu o excepcional crescimento urbano de São Paulo ao desenvolvimentoda indústria orientada para o mercado interno. $\mathrm{O}$ grande mercado cativo da cidade constituído por esta e por seu hinterland permitiu a sua indústria produzir em maior escala e, assim, vender mais barato que seus competidores de outras regiōes do Brasil, inclusive os do Rio de Janeiro, centro que na primeira década deste século ainda era o principal parque manufatureiro no país.

Para ele, $\mathrm{em}$ poucos decênios todo o mercadobrasileirose tornou o mercado da indústria paulista, promovendo a acumulaçăo de capital e o crescimento demográfico da cidade. A incapacidade do Rio de manter ritmo semelhante, apesar de seu maior mercado enquantocentro urbano, é considerada consequiência do baixo poder aquisitivode seu hinterland, cuja produção agrícola de exportação entrara em colapso desde ofim do trabalho escravo.

A explicaçāode Singer, portanto, é feita de uma perspectiva que insere o urbano no regional e baseia-se no tamanho da demanda. Sua tese merece ser mantida enfatizandose que o mercado original da indústria paulistana constituiu-se das empresas com mão-de-obra livre, de seus proprietários, e dos trabalhadores assalariados em geral, englobando nāo só a capital mas também a próspera rede urbana no interior do estado.

Noentanto parece insuficiente entender que as forças concentradoras do mercado foram reorientadas do Riopara SãoPaulo por obra da própria mão invisível, como Singer defendeu com brilho. Há que se procurar o corpo social e político atrás dela, há que se supor a ação deliberada de grupos poderosos expressando-se por seus gestos. Também o conceito de hinterland usado desqualificadamente por Singer pode ser enriquecido. Neste trabalho hinterland é entendido como território cuja unidade é maissociopolítica doque natural poisé dada pela mobilizaçãoc drenagem de seus recursos por um núclcourbano polarizador, através de iniciativas e controles adotados por uma classe dominante local e sua elite dirigente, atuando através do Estado.

Aoenfatizar-se a atuaçāo político-econômica de determinados grupos nãose está cogitando de um complô para derrotar o Rio. Está-se pensando, sim, em diferenças nas estratégias de acumulaçảo a curto $\mathrm{e}$ médio prazos aplicadas por conjuntos articulados de investidores baseados $\mathrm{em}$ cada uma das cidades. A intenção é enfatizar a história traçada por açōes escolhidas e praticadas por segmentos sociais capazes de com elas afetar o conjunto da coletividade. Tal abordagem prestigia os agentes mas não permite desvios voluntaristas pois faz ver as opçōes dos setores de classe surgindo, a partir de possibilidades estruturadas por práticas sociais anteriores.

Isto permite que se examine a dinâmica das economias do Rio e de São Paulo tanto do ponto de vista amplo, da formação ou oferta de capitais, como do mais restrito, enquantoopçöes de investimento feitos por grupos burgueses, levando-se em conta circunstânciasque presidiram orelacionamento de personagens locais com aplicadores $\mathrm{e}$ promotores externos.As hipóteses a serem exploradas derivam doordenamento teóricode pontos esparsos em diferentes estudos de natureza histórica, econômica, social e geográfica arrolados adiante na bibliografia. Elas podem ser sumarizadas em quatro pontos, como se segue:

1. Cada uma das cidades desenvolveu seus próprios processos de acumulação de capital e de formação da burguesia, com roteirosindependentes desde antes docafé até a fase madura, em meados do presente século. Adiversidade de interesses dessas duas burguesias impediu a subordinação dohinterland de SãoPaulo às forças sociais metropolitanas do Rio, mantendo as áreas de influência imediata das duas cidades como regiōes separadas durante todo o período aqui examinado.

2. Diferenças cronológicas na fase de apogeu de acumulaçāo das duas burguesias fizeram com que enfrentassem condiçōes diversas de competiçāo estrangeira devido a alteraçōes nos padrōes de comércio internacional e nas políticas européias de investimentoexterno. (.onseqüentemente, cada uma foi confrontada com diferentes opções de investimento, afetando sua preferência ou não pela produção em si, o que viria a influenciar o escopo de desenvolvimento capitalista que permitiu a si mesma e à sua cidade. 
3. A atitude das duas burguesias em relaçāo ao investimento na indústria nāo foi a mesmae isso, naturalmente, influenciou a evolução das duas economias regionais. No Rioocapital mostrou-se desinteressado $\mathrm{em}$ aproveitar plenamente as oportunidades abertas pela abundância do trabalho livre barato, logo desviando-se das atividades agricolas e manufatureiras para outras provavelmente tanto ou mais lucrativas, mas de alto caráter especulativo e baixo caráter multiplicativo, tais comoas transaçōes imobiliárias e a construção urbana, além da intermediaçâocomercial e financeira. Já a cconomia de São Paulo, desde o começodo período cafeeiro, vinculou-se mais especificamente à produçẩo em si.

\section{Ambas as burguesias tentaram e con-} seguiram usar o Estado para promoção de seus interesses privados. Contudo, enquanto em Sảo Paulo essas práticas resultaram em políticas oricntadas para incentivo $\mathrm{e}$ proteção da produçâo do café, clevandoo nívelde atividades econômicas c beneficiandovárias camadas burguesas além de outras classes sociais, no Rio o dinheiro e as políticas do Estado foram usadas promovendo serviços c obras urbanas. A burguesia do Rioparece ter tido objetivos cujos resultados imediatos para os bolsos privados c para as feiçōes da cidade foram brilhantes, mas não lograram causar impacto maior nodesenvolvimento a longo prazo da cconomia local. O comércio, incluindo o tráfico negreiro, $\mathrm{c}$ as fazendas escravistas foram, tanto no Rio comocm São Paulo, as origens do enriquecimento que precedeu à acumulação de capital baseada no trabalho livre e na indústria. Dessa aparente similaridade emergiram, contudo, diferençassuficientemente fortes para prover São Paulo com um setor produtivo sempre crescente $\mathrm{c}$ para fazer o Rio desprezar a agricultura e negligenciar a indústria. $O s$ pontos a notar $\mathrm{em}$ cada caso dizem respeitoà natureza das respectivas atividades comerciais, à relaçāo que estas man-
RUA QUiNZE DE NOVEMBRO, FOTO TIRADA ENTR: $1005 / 1906$

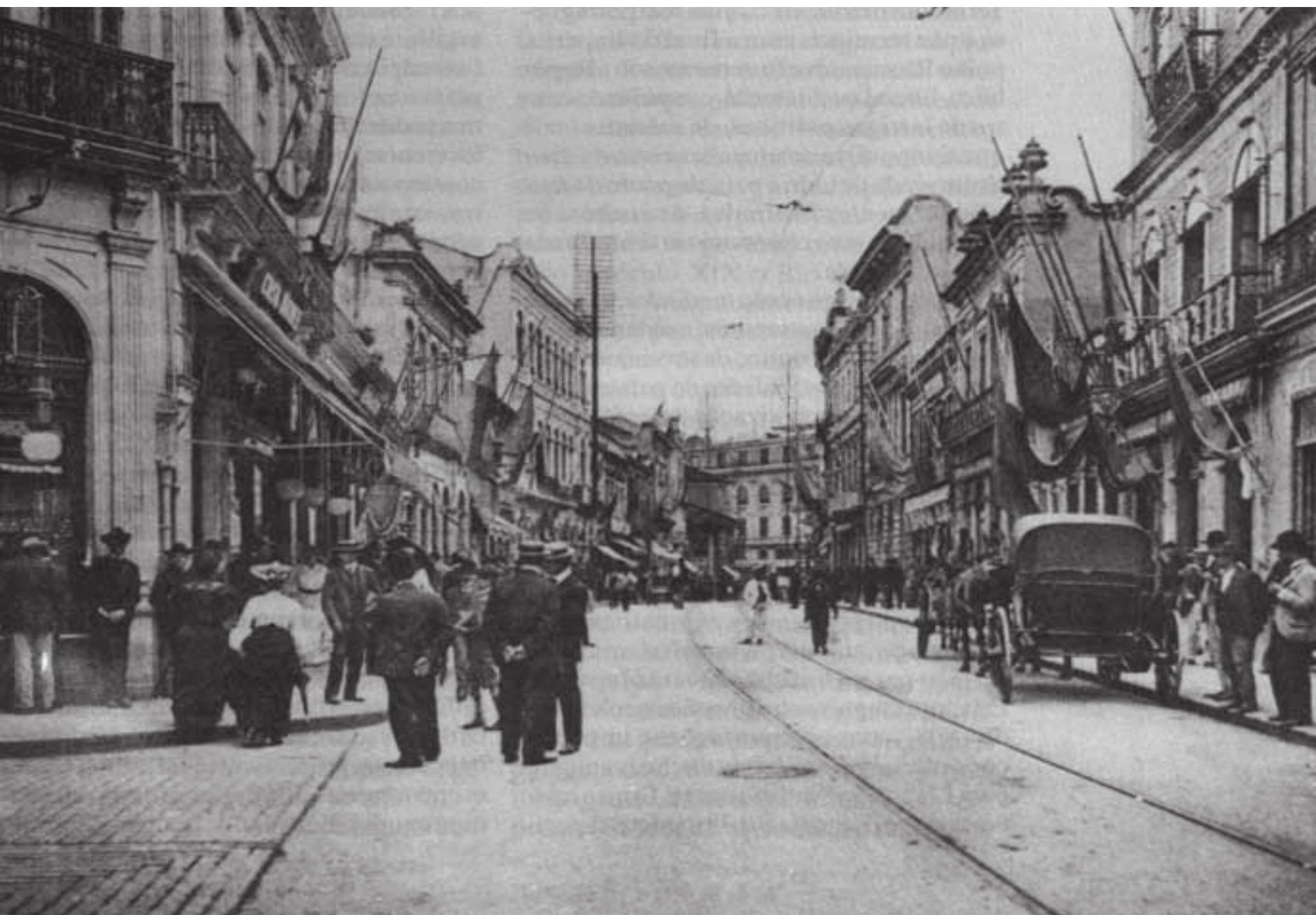


tiveram com a produção $\mathrm{e}$ às opçōes cconômicas oferecidas a diferentes grupos sociais.

\section{C O M E R C I A N T E S, F I N A N C IS T A S E FAZENDEIROS NORIO}

A prosperidade do Rio liga-se ao comércio desde a época do ouro, quando seu portose tornou o único acesso legal ao mar, para as riquezas das minas, bem como sua porta de entrada para imigrantes lusitanos, escravos negros e bens de consumo importados. As principais casas comerciais portuguesas, especialmente os traficantes de escravos, instalaram ali seus agentes. $\mathrm{O}$ abastecimentodas cidades auríferas vinculado ao comércio marítimo, ao transporte e ao crédito, fez, então, do Rio, ponto por excelência de drenagem e controle da produção colonial pelos poderes metropolitanos europeus - e nãosóde Lisboa, pois após Methuen o ouro brasileiro facilitou as transaçōes orientais da Inglaterra e alimentou o crescimento da Cityem Londres.

Graças ao ouro a cidade foi elevada à condição de capital, ainda no vice-reino, $\mathrm{em}$ 1763. Seu caráter de corte começou em 1808 com oexílio da família real portuguesa e nāo terminou com o final do Império, pois o Rio manteve fortemente sob a República, liberal ou ditatorial, o espírito docentro de intrigas políticas, de moradia mais que temporária de uma rica camada dirigente vinda de todo o país, de ponto de reunião de mentes ilustradas, de enclave de consumo de uma classe ociosa tāo refinada quanto alienada.

Comocorte e como mediadora comercial entre dois continentes, a cidade foi-se atribuindo o dom mítico de servir à acomodaçâo entre as rusticidades do país e as glórias ou o luxo da civilização externa, virtude de aliar incompatibilidades até hoje celebrada no carnaval (Matta).

Com a ascensāo do café, logo no início doséculo XIX, novamente o comércioprimordial foi o dirigido a além mares, dominadopor empresas estrangeirase localmente comandado por agentes năo-nativos que, com relaçăo aos lucros, transferiam a parte do leāo para a Europa. Até o colapso do Estadoportuguês sob a invasãonapoleônica de 1808 , todas as exportaçōes $\mathrm{c}$ importaçōes oficiais eram feitas exclusivamente para Lisboa ou Porto por essas firmas lusitanas ou por negociantes britânicos especi- almente autorizados a se estabelecerem e operaremem Portugal. Depois de transferida a corte para o Riode Janeiro, a Grã-Bretanha obteve odireitode ali manter suas empresas comerciais, eliminando o intermédio das firmas mercantis portuguesas e abrindo espaço para o surgimento de um agente brasileiro, o comissário de café.

Acompreensãodas relações de dependência que se estabeleceram entre o financiamento externo, o comércio interno e a produção do café passa pelo acompanhamentodotrajeto feito pela riqueza produzida pelos escravos. Ela era dividida, dentro do Brasil, entre três principais grupos sociais: os proprietários de fazendas, que quase sempre moravam em suas terras administrando a produção do café; seus agentes no Rio, que vendiam seus produtos por comissâo; e os representantes das casas comerciais britânicas, que compravam esse café e embarcavam-no para fora. Laços de crédito conectavam esses grupos na direção contrária: os negociantes britânicos, apoiados por firmas comerciais inglesas que descontavam os títulos dessas transaçōes na City de Londres, forneciam à taxa corrente de juros créditopara os agentes comissionados docafé os quais, por sua vez, o repassavam aos fazendeiros sob a garantia de sua safra seguinte ou de seus escravos e terras. Os fazendeiros usavam odinheiro para comprar escravos, ferramentas e bens de consumo, todos adquiridos através de seus agentes comissários estabelecidos no Rioou em contato com o Rio a partir de cidades menores, como as do Vale do Paraíba. Nesta economia, a circulaçāo de dinheiro era insignificante e quase que completamente circunscrita à capital. A maioria dos fazendeiros tinha na verdade muito pouco controle sobre as contas dos seus negócios, geridos na esfera da circulaçẩo pelos comissários(Stein, Franco, Levy).

Até a metade do século XIX esse sistema funcionou satisfatoriamente, permitindo a expansâo das fazendas sem maiores problemas. Alguns comissários de café, por negociarem com vários fazendeiros, tinham enriquecido o suficiente para operarem quase como banqueiros locais, emitindo vales e outros títulos semelhantes. Ocrédito para a produção havia se tornado menos difícil. A partirde 1860, contudo, emissários de café e fazendeiros do Rioentraram em bancarrota, processo ao qual a aboliçāo da escravatura em 1888 apenas daria um último toque. Este colapso ocorreu por dois 
motivos principais. De um lado, os credores britânicos exigiram, cobrando a divida que o Brasil herdara de Portugal comopreço da independência política ou condicionando a isso o fornccimento de novos recursos para fins militares $\mathrm{e}$ infraestrutura ferroviária, a convertibilidade da moeda brasileira ao ouro, medida cuja contrapartida foi a redução docrédito interno pelo governo. Por outro lado os fazendeiros haviam se endividado acima de suas possibilidades para a compra, $\mathrm{em}$ outras regióes do país, de escravos, cujos preços tinham crescido enormemente desde a extinção do tráfico negreiro internacional em 1850.

Com a redução do crédito, os fazendeiros náo foram mais capazes de substituir escravos depauperados depois de sete ou oito anos de vida ativa nas fazendas de café. Conseqüentemente, todoosistema produtivo foi sendo solapado. Sem o trabalho compulsório não havia como plantar, tratar e colher café. Os fazendeiros nâo eram capazes de prevenir a erosão do solo, ou de regenerá-lo, ou de abrir novas fronteiras. Faliram e nunca se recuperaram(Stein).

Neste sentido, a dependência externa junto com a incapacidade de controlar os mais importantes patamares da comercialização, de construir um sólido sistema de crédito orientado para a produção, de conceber e estabelecer formas de trabalho alternativas à escravidão levaram ao abortoo embrionário capital produtivo do Rio. Estas foram as razöes pelas quaiso café do Vale do Paraíba, apesar de haver penetradooterritórioda vizinha província de Sảo Paulo, não teve forças para seguir adiante incorporando novas áreas e mais populaçäo ao hinterland do Rio. Esses mesmos fatores deram chance para que as muito menores fortunas comerciais de $\mathrm{Sāo}$ Paulocriasseme desenvolvessem uma economia de exportação própria, lcvando-a muito além na escala capitalista do que o café fluminense conseguiu.

Éverdade que alguns dos fazendeiros do Rio mudaram-se para o próspero oeste de SảoPaulo na segunda metade do século XIX. Mas eles formaram apenas a exceçâo que confirma a regra, já que nảo lideraram essa nova expansẩo da economia do café, mas, aocontrário, foram atraídos por cla. A fragilidade da maioria dos fazendeiros de café do Rio já foi atribuida, ao menos em parte, às suas origens rurais e ao seu isolamento(Granziera). Na verdade alguns de- les eram ex-roceiros cujos antepassados tinham se engajado na mineração do ouro (Stein). Masdestacavam-se outros, muitas vezes portugueses, que, depois de alguma experiência nocomércio local, estabelece. ram-se como fazendeiros, tornando-se grandes proprictários de terras e de escravos. Esse foi o caso, por exemplo, do fundador da família Werneck, uma das mais ricas e famosas do interior do Riodurante o Império. Outras famílias como os Teixeira - cstudados por Stcin -, que vieram das minas e enriqueceram na provinciana cidade de Vassouras tanto com a produção $\mathrm{c}$ comercializaçảode café comocom empréstimode dinheiroe especulaçáo com terras, logoviramalguns de seus membros na corte atuando como comissários de café e banqueiros. Um terceiroexemploé dotraficante de escravos que também se tornou grande proprictáriode fazendas $\mathrm{e}$ famoso como líder local de uma rebeliāodescentralizadora em 1842, Souza Breves, a quem se atribuía a propriedade de seis mil escravos e nada menos do que 30 fazendas que juntas produziam até três mil toneladas de café por ano, sendo consideradoo homem mais rico de toda a província do Riode Janeiro(Bethell e Carvalho).

O verdadeiro problema é até onde os fazendeiros fluminenses chegaram noprocesso de desenvolver uma burguesia urbana ou, $\mathrm{em}$ outras palavras, em que medida se valeram da cidade do Rio como seu centrode contatossociais, informaçāo, diversificação dos negócios e articulação política para obter medidas protetivase privilégios econômicos dogoverno central. Durante todo o século XIX o Rio de Janeiro foi indubitavelmente a metrópole nacional exatamente porque se tornou e permaneceu sendo o ponto de encontro e amálgama dos proprietários de terra dos quatro cantos do Brasil.Os produtores do Rioestiveram bem representados entre eles, e sua influência cresceu na mesma medida que a importanncia do café na economia nacional. Porém, as políticas que os uniam a todos foram, $\mathrm{em}$ primeirolugar, a manutenção da escravidão como a instituiçâo social básica e, $\mathrm{em}$ segundo, a eliminaçăo de qualquer perigo de retorno ao domínio e à intermediaçâo comercial por Portugal, de forma a capacitar à economia vender diretamente à GrãBretanha e receber de lá bens a preços mais baixos. Isto é, dois objetivos que iriam a longoprazoestabelecerum limite para suas possibilidades de acumulação do capital 
contínua c autônoma.

Por essas razōes estruturais, o Rio ironicamente evoluiu para uma posição de metrópole intermediária, como Lisboa tinha sido antes, entre Londres e a cconomia brasileira. Suas funçōes comerciais como um pontode redistribuição de mercadorias estrangeiras tomaram-se muitomaisimportantes do que aquelas derivadas de sua posiçáo econômica e administrativa $\mathrm{em}$ relaçâo a um hinterland produtivo. Adiversificaçãode seus setores capitalistas, durante o progressivo eliminar da escravidão, ou mesmo após, nāo esteve conectada às bases originais da produçãoagrícola circundante. A indústria manufatureira, por exemplo, obteve capital de muitas fontes diferentes, entre as quais o tráfico de escravos, cuja sede estava no Rio há longo tempo, $\mathrm{e}$ a coleta dos fundos privados locais dispersos nas camadas abastadas, através da promoção especulativa de açōes industriais.

Odinheirodo tráfico de escravos provavelmente ajudou a expansão da manufatura no Rioque ocorreu desde 1850, depois da proibiçáo inglesa desse comércio nas águas internacionais e osimultâneocstabelecimentode legislação que modernizava a constituiçâo de cmpresas no Brasil (Lobo, Greenhill, Soares).

Algumas empresas manufatureiras, principalmente na indústria têxtil, já estavam instaladas naquele período. As capacidades empresariais capitalistas já tinham sido assimiladas por brasileiros como pode ser visto pela carreira de Mauáque, depois de ter sido auxiliar de escritório, gerente e sócio de uma firma britânica, começou a atuar com relativa autonomia, expandindo seus próprios negócios de risco por várias atividadeseconómicas urbanas, comotransportes, fábricas e bancos, nāoapenas no Rio mas também em diferentes partes do Brasil e até mesmo na Argentina e Uruguai (Manchester).

Um ponto a ser notado na biografia de Mauá é que veio a perder toda a sua fortuna devidoà falta de apoio que ele esperava do governo brasileiro, negado $\mathrm{em}$ nome dos princípios liberais. Esse episódio mostra como as elites dirigentes daquele tempo, apesar de não imunes a favorecimentos pessoais, não consideravam as atividades de Mauá como parte importante da cconomia regional, para nảo dizer nacional, guardando, dessa forma, perfil pouco definido $\mathrm{cm}$ termos de política econômica c aceitandoplenamente as proclamadas virtudes da divisâo internacional dotrabalho.

Provavelmente por causa desses tipos de incertezas, o tráfico internode escravos e a emissão, na metade da década de 1860 , de bônus governamentais para finalidades militares(a guerra contra oParaguai) foram capazes de atrair mais recursos inativos do que qualquer atividade produtiva. Esse desinteresse dos capitalistas do Riopela organização da produçāo baseada no trabalho livre parece ser absolutamente surpreendente num tempode crescente escassez de mâode-obra que perdurou até a abolição definitiva da escravidāo em 1888; ainda mais porque exatamente oopostoocorria na província de Sảo Paulo, como será relatado adiante. Os bons lucrosque eles obtiveram através de outras atividades devem ter distraído sua atenção dessa oportunidade.

A política de crédito fácil do novo governo republicano conduziu, no começo dos anos 90 , à frenética promoçảo de açōes de companhias que se tornou conhecida como encilhamento. Este boom foi capaz de deixar, junto com um grande númerode falências, um decisivo ponto de partida in. dustrial para produzir na cidade do Riouma expansão da capacidade instalada que envolveu as cidades vizinhas de Petrópolise Nova Friburgo (Stein, Vand der Weid e Bastos, Levy e Saes). Deste momento em diante a indústria do Rio teve que se apoiar quase que exclusivamente nos seus próprios ganhos. Isso não foi difícil de conseguir porque, de um lado, otrabalho era baratoa cidade vinha recebendo ao longo de várias décadas fortes levas de imigrantes espontâneos (principalmente de origem portuguesa)- c depois da aboliçáo atraiu parte da populaçáode ex-escravos do interior do estado. De outro lado, o mercado estava crescendo. Graças à instituiçāo dos salários e apesar de serem baixos, a demanda por produtos manufaturados se expandia ediversificava. Este último aspectoconduziuà substituiçãodas importaçôes.

Mas, na sua maior parte, os estudos sobre a industrialização do Brasil concordam que este processo tornou-se possível principalmente pelas medidas governamentais para proteger os lucros dos fazendeiros e negociantes de café ao custo da desvalorização do cámbio da moeda nacional. Tais políticas obtiveram apoio entre cafeicultores do Rio, mas foram planejadas e imposlas pela burguesia do café de São Paulo, cujodesenvolvimento apresentara caracteristicas bastante especificas. 
IV. O COMPLEXO

ECONOMMICO

\section{CAFEEIRO PAULISTA}

Como no caso do Rio, o comércio foi a atividade original dos mais proeminentes cafeicultores de São Paulo, o que os caracteriza menoscomoindivíduos presos aosolo e mais como homens mobilizados pelolucro. Antônio Prado, um português que imigrou no último quartel do século XVIII e fundou uma dinastia de grandes proprictários de fazendas de café, homens de negócioe políticos, foi inicialmente comerciante no interior da Bahia e depois, a partir de SảoPaulo, intermediou oabastecimentodo Rio com gadosulino, cujo monopóliotentou obter. Foi ainda colctor de impostos nos caminhos para o atual Paraná e o RioGrande. Ingressou posteriormente na produçāo de cana-de-açúcar e café (Petrone). Seus descendentesacrescentaram a este conjuntode atividades a corretagem do café, bancos, construção e exploraçảo de estradas de ferro, além de manter até o século XX importantes cargos governamentais.

Outro que conseguiu a posição de coletor de impostos, chegando a senador vitalício e, por breve período, regente do Império, foi Vergueiro, cuja fama se associa à introduçăo de colonos europeus nas fazendas de café. Chegandode Portugalem 1802 , obteve terra de graça nooeste paulista e foi um dos primeiros a substituir a canade-açúcar pelo café, em 1828. Sendotambém um traficante de escravos, em 1847 , encarou a determinaçāobritânica de pôr um fim a este negócio, pedindoe obtendo ajuda governamental para trazer europeus como mão-de-obra para fazendas suas e de terceiros e transformou isso numa atividade lucrativa, estabelecendouma companhia para importar trabalhadores numa condição de comprometimento por dívidas, como os indeturedsenvants, para fazendeiros $\mathrm{em}$ São Paulo, Rio de Janeiro e Minas Gerais.

Estes exemplos servem para mostrar como a burguesia emergente $\mathrm{em}$ SảoPaulo aprendeu a enxergar o café como um conjuntode atividades cconômicas interligadas, àsquais políticas específicas de Estado poderiam ser de grande estímulo por aumentar os lucros privados através de recursos públicos. Ao mesmo tempo, há várias evidências de que essa burguesia foi também rápida $\mathrm{em}$ definir alianças c oposiçōes comoutros grupos sociocconômicose dentrode suas próprias fileiras. A conexão fer- roviária doplanaltocom o mar exemplifica este tipo de mobilização para a expansāo das fazendas. Ela produziu em São Paulo uma forte oposição ao maior empresário urbano do Rio de Janciro na época, o já mencionadoMauá, que obtivera concessóes para estabelecer c operar uma cstrada de ferrona área, masque, por uma razāoou por outra, estava postergandosua construção. A burguesia paulista bem comoos capitais britânicos envolvidos na transação preferiram eliminar a participação de Mauá no negócio(Malton Jr.), e a estrada ficou pronta $\mathrm{em}$ poucos anos. A ferrovia foi um dos mais lucrativos empreendimentos ingleses na América Latina pois permaneceu com monopólioda transposiçáodaSerra doMar na região de São Paulo até bem entradoo século XX, só sendo nacionalizada após a Segunda Guerra Mundial. Foi também uma transação germinativa de lucros para os empresários locais na medida em que imediatamente após a conclusão dessa linha, em 1867, eles trataram de conectá-la a outras, assumindo novos empreendimentos ferroviários com recursos próprios ou empréstimos externos sob garantia estatal. Dessa forma, assentaram trilhos por toda a província e conquistaram para oboom do café paulista território ainda por desbravar. Algumas dessas ousadias prosperaram, outras acabaram logo incorporadas pelo Estado, nãosem antes permitir bons negócios com terras $\mathrm{c}$ o assentamento rural $\mathrm{e}$ urbano em antigas florestas ou campos naturais, ambas constituindo em sua expansão o conjunto do hinterland da capital.

Os mais esplendorosos tempos para a burguesia cafeeira e para a cidade de São Paulo não aconteceram antes do último quartel doséculo XIX, quandoo Estado foi de novo mobilizado, dessa vez para solucionaroessencial problema da mảo-de-obra. Comoé bem conhecido, oestabelecimento no final dos anos 80 de instituiçöes republicanas resultou numa estrutura de poder político federalizada e descentralizada, mas ambos os governos, federal e estadual, foram conquistados pela burguesia do café de São Paulo, que junto com os políticos de Minas Gerais tornou-se a oligarquia governante até 1930. Mesmo antes da República, fundos públicos nacionais e locais foram conquistados por essa gente para pagar pelo transporte e distribuiçāo de trabalhadores livres europeus (e mais tarde também japoneses), evitando assim o endividamento que ocorrera com aqueles 
trazidos por Verguciro c cuja revolta tinha cstancado influxo de máo-de-obra por algumas décadas. Com a República a prática pôde tornar-se rotincira.

Houve, da parte da burguesia paulista, cuidadoem assegurar um suprimento abundante e barato de mảo-de-obra, oque tornava excedente uma parcela dos trabalhadoresimigrantes antes mesmode chegarem às fazendas; nestas, por sua vez, o declínio periódico dos preços de café diminuía ganhos complementares ao salário fixo. Por cssas razöes centenas de recém-chegados tiveram que permanecer na cidade de São Paulo, mercado de trabalho oficializado através da Hospedaria dos Imigrantes, o que tendia a fazer cair os salários urbanos e industriais. Muitos foram capazes de conseguir ocupação de ganho na própria São Paulo, que nofinal doséculo XIX tinha uma população italiana maior do que a nativa. Tambémos fazendeirostenderam cada ve $z$ mais a se mudar para a cidade, não apenas para ter maiores condiçöes de confortocom suas familias, mas também para tomar parte em outras atividades políticas, sociais e econômicas.

Logo que o problema da mão-de-obra foi solucionado $\mathrm{c}$ que o acesso às férteis terras virgens tornou-sc possível pelas estradas de ferro, os estímulos dos mercados de café americano c curopeu puderam resultar na forte expansãodas fazendase na aceleração da acumulação do capital $\mathrm{cm}$ São Paulo. Seus maiores fazendeiros financiavam os menores c também auferiam grandeslucros da venda de terras expropriadas aos índios e rocciros de subsistência ou a eles doadas pelo governo do Estado. Também neste caso, o capital estrangeiro controlava os últimos estágios da comercialização externa e logo começou a engolir comissáriose até fazendeiros de café. Mas os britânicos não cstavam mais sozinhos nessa cmpreitada e tiveram que enfrentar uma competição crescente da parte das companhias alemăs $\mathrm{e}$ americanas. A burguesia cafccira paulista foi muito hábil na exploração desse espaço de manobras limitado, de um lado, pelos Rothschild (Iradicionalmente o principal credor do Brasil) c, de outro, por recém-chegados como o Disconto Gesellchaft, o Nordeutsche Bank of Hamburg, o Schroders of London, a Societé Generale de Paris co First National City Bank of New York (Monbeing). Em 1906 essa burguesia foi capaz de montar uma estratégia defensiva para proteger $\mathrm{c}$ promover os preços internacionais do café por meio de um acordo com os produtores do Rio de Janciro e de Minas Gerais e pela obtençãode cmpréstimo externo para a organizaçăo de estoques reguladores do produto(Furtado, Monbeing, Love). Essa cstratégia resultou $\mathrm{em}$ sucesso absoluto $\mathrm{c}$ foi mais tarde repetida diversas vezes com o necessáriosuporte dogoverno federal.

Por outrolado, a burguesia paulista foi indiretamente protegida dos avanços do capital externo na cconomia regional pela evolução dos eventos internacionais. Oinfluxo desse capital tem sempre sidocíclico, refletindo os problemas de suas matrizes com as tendências geopolíticas de diversificação $\mathrm{cm}$ suas aplicaçōes. A Primeira Guerra Mundial interrompeu o influxo de crédito advindodo acordode $1906 \mathrm{e}$, definitivamente, pồ um fim à supremacia britânica no pais como no mundo. A crise de 1929 e a Segunda Guerra Mundial atuaram na mesma direçăo com respeitoà Alemanha $\mathrm{e}$ aos Estados Unidos, cujos capitais aqui só puderam retornar para valer na metade dos anos 50(Manchester, Dean).

Outro ponto conhecido de expressão de interesse coletivo foi a atuação da burguesia cafecira, liderada pela representaçáo paulista no governo federal, sobre a política de càmbio. Ante a guerra internacional do preço do café, sucessivas desvalorizações da moeda brasileira garantiam a prosperidade da cconomia cafecira através doque Furtado, adequadamente, designou "socializaçúodasperdas", jáque negociantes c fazendeiros recebiam pelo café $\mathrm{cm}$ moeda forte c pagavam trabalhadores, insumose custos de transporte com dinheiro nacional de valor declinante. Neste caso, o interesse da burguesia contrapôs-se não só ao das classes assalariadas locais mas também aodos financiadores externos. A Grä-Bretanha tentou reprimir esse processo na medida do possivel, e as oscilaçöesda politica monetarista refletiram, até a crise de 1929, exse conflitode interesses(Fritsch). Os fazendeiros de café brasileiros nãocram mais adeptos incondicionais do liberalismocconômico.

O fato mais importante é que a marcha de desenvolvimentodeterminadopelocafé na economia regional permitiu uma expansäogeneralizada de empreendimentos, proporcionando ganhos a diferentes grupos dentro do espectro social. A indústria manufatureira surge noestado de SãoPaulo, e mais particularmente na cidade de Sáo 
Paulo, comoum subprodutoda prosperidade material Irazida pelo crescimento da cconomia cafecira. Ela fezparte doque Cano chamou de o complexo cconômico cafeciro - isto é, uma estrutura capitalista setorialmente diferenciada $\mathrm{c}$ de auto-reforço interno, que dependia basicamente da produçāo c exportação do café. A oferta abundante do trabalho relativamente qualificado de imigrantes nâo-organizados favoreceu a indústria porque isso significava baixos salários além de um cuidado inteligentedas máquinas c uma auto-regulaçâo do trabalhador, oque nâo poderia ser esperado de escravos.

Pelo menos três diferentes grupos sociais investiram na indústria manufatureira paulista. Alguns fazendeiros o fizeram em ocasiōes em que o preço do café veio abaixo, reduzindo suas margens de lucro, e também quando a política de defesa desses preços começou, porque ela requeria alguma contenção na expansão das plantaçôes de café. Eles exploraram o mercado fornecido por sua atividade principal, produzindo têxteis para sacaria de café assim como roupas e sapatos para seus trabalhadores. Um caso diferente é ode Rodovalho, mistura de fazendeiro e comerciante, que preferiu introduzir a indústria do cimento no estado. Um segundogrupo foi constituído por importadoresque também investiram para substituir bens que traziam do exterior, devido a dificuldades na obtenção de moedas fortes para comprá-los e fazendo uso dos seus conhecimentos sobre necessidades específicas do mercado local(Dean).

O terceiro grupo é dos imigrantes parventıs. Mas não correspondendo exatamentc ao mito do homem destituido, porém poupador, que cria pouco a pouco, peloseu trabalho, um fundo de investimentoe cresce da pequena firma ao complexo manufatureiro. Exsa versāodo sensocomum foi posta $\mathrm{cm}$ novos termos pelo estudo de Souza Martins sobre o conde Matarazzo, mostrando que os mais bem-sucedidos na verdade obtiveram seus capitais expropriando-os através do comércio com pequenos proprietários rurais e/ou contaram com o suporte de bancos, muitas vezes, cstrangeiros. Há tambémalguma evidência, como quarta origem da indústria paulista, do capital externoter sido invertido nesse setor desde os primeiros anos do século $\mathrm{c} \mathrm{cm}$ quantias maiores do que as demonstradas pelos dados até agora (T.Szmrecsanyi).

Essa multiplicidade de origens tornou a indústria paulista não só mais flexível para aproveitar oportunidades em diferentessegmentos do mercado, mas também menos vulnerável à crise da cafeicultura $\mathrm{cm}$ cuja sombra se originara. Sem ficar imune à recessāo dos anos 30 , mostrou crescimento ainda na primcira metade da década $c$ absorveu rapidamente os estímulos da política conômica do Estado Novo, assim como da Segunda Guerra, mesmoque lhe faltassem condiçōes de suprimento $\mathrm{em}$ bens de capital.

Que a resposta de Sāo Paulo a tais estímulos foi bem mais intensa que a do Rio, pode-se constatar através da comparaçāo da participação de cada um novalor da produçāo industrial brasileira. Segundo Ratner, em 1907, a cidade do Rio contribuía com $33,1 \%$ desse valor, enquanto todo o estado de São Paulo contribuía apenas com $16,5 \%$. Mas, em 1938, a situaçāo era mais do que proporcionalmente inversa pois a produçăo da capital federal reduzira-se a $14,2 \%$, valor nacional, enquanto a produção paulista já atingia $43,5 \%$.Sabendo-se que omunicípio de São Paulo concentrava a maior e melhor equipada parcela da indústria do estado, a ponto de a cidade com sua área metropolitana chegar a responder em 1960 por nada menos do que $87,4 \%$ do valor da produçāo do estado, compreende-se que cedo sua indústria deixara a do Rio para trís.

Para Singer, a produçāo manufatureira mais do que o café ou qualquer out ro setor ou atividade cconómica isoladamente foi a causa real do crescimento demográfico de Sâo Paulo na primeira metade do século $\mathrm{XX}$. Ele salientaque, de acordocom Roberto Simonsen, a indústria doestadode SãoPaulo estava crescendo mais depressa do que a do cstado do Rio desde 1905 e que, scgundo seus próprios cálculos, nesse setor o Rio foi definitivamente ultrapassado durante a década de 20.

\section{A CIDADE COMO CAMPO DE INVESTIMENTO}

Ambas passando por intenso crescimento demográfico e sendo mercados de capitais, Rioe Sảo Paulo logodescobriram $\mathrm{cm}$ seu próprio corpo algumas excelentes oportunidades de investimento. Oestilotradicional de exploraçâo imobiliária, ou seja, a arrecadação de aluguéis, foi cedendo lugar a modos mais dinâmicos e empresariais 
de aproveitamento económico (Ribeiro). Tanto a intensificação do uso da terra já urbanizada e da infra-estrutura já existente como a criaçảo de novos espaços urbanizados nas fríngeas da cidade foram postas em prática.

Por um lado, como mostra Toledo, de 1870 a 1975 ocentro de Sảo Paulo teve três faces, poisolocus da vila setentista foi duas vezes demolido e reconstruído, verticalizando-se a partir da década de 20 . No mesmo período, o raio da circunferència fictícia capaz de compreender toda a área urbanizadacresceu de menos de 3 paraquase 30 quilômetros, correspondendo à extensảo real da faixa edificada especialmente nasáreas sul c leste. Por outrolado, a forma longitudinal do Rio, devida à sua localiza. ção entre o mar cos morros íngremes, também proporcionou verticalizaçấo c alongamentoda distância entre os extremos urbanos.

Em ambos os casos, isto ć, o assentamento intensivo e extensivo, a produção material da cidade foi um processo comandado pelo capital $\mathbf{e}$ dedicado aos scus lucros, mas apenas parcialmente levadoacabo por cle. O Estado foi freqüentemente um parceiro nem sempre obscuroda iniciativa privada. Recursos financeiros de diferentes origens (estrangeiros e nacionais, locais e de outras regiöes brasileiras) reunidos $\mathrm{cm}$ capitais de diferentes potências, sob a forma de grandes sociedades anônimas às vezesinternacionais, de sociedades limitadas com porte médio, de pequenos negócios de um só dono ou de uma só família foram aplicados $\mathrm{em}$ atividades mutuamente complementares orientadas para a urbanização crescente de algumas áreas. Esses capitais nãoapenas foram capazes de colaborar entre si como também mostraram-se aptos a obtero apoiodo Estado na provisảo de serviços públicos essenciais, na regulaçăo do pareelamento de terras com venda de lotes e na criação da infra-estrutura física dos sistemas de transportes e saneamento.

Na passagem do século, o Rio de Janeiro, por seu maior tamanho e sua importância política comocapital do país, revelavamelhor doque Săo Pauloessas formas de acordoentre capitalistas e oEstado. Devido às suas funçōes administrativas nacionais, a cidade teve facilidade em receber recursosdoorçamento federal ou em obter apoio do governo da República para contrair e pagar empréstimosinternacionais destinadosà melhoria das suas condiçöes sanitári- as, bem como ao embelezamento de logradouros públicos.

Esse suporte federal foi indispensável à modernização urbanística do Rio e sua constituiçảo em cartão de visita (ou postal) do país. Os gastos governamentais em sua área urbana, feitos em escala muito maior do que a ocorrida em São Paulo nesse período, desempenhavam um papel dinâmico na economia que transcendeu os limites do município, sendo responsável por boa parte da atração que seu mercado de trabalho exerceu sobre áreas cconomicamente letárgicas dos estados do Rio, Minas Gerais, EspíritoSantoe Nordeste.

Os investimentos estrangeiros em serviços públicos ocorreram durante toda a segunda metade do século XIX c nos primeiros anos doséculo XX. A oferta de capital nas bolsas internacionais sendo abundante, companhias foram formadas por promotores de açốes, mediante a concessảo pelo Estado, por um determinado número de anos, do direito de exploraçáo do serviço. Saneamentobásico c fornecimento de água, transportes urbanos ou a grande distância (estradas de ferroc portos), gáse eletricidade constituíramos principaiscamposde aplicaçăodesses capitais. Transportes e comunicaçóes eram requisitos para a expansão dasáreas urbanizadas. Capitalistas locais, interessados na valorização $\mathrm{c}$ abertura de novos assentamentos, freqüentemente ajudavam com a sua influência pessoal as companhias estrangeiras a obter ou renovar suas concessões. Nesse sentido, por exemplo, empresas estrangeiras abriram, no começo desse século, um túnel sob o morroque até então havia dificultado o acesso às praias de Copacabana, Ipanema c Leblon, áreas cuja valorização imobiliária foi colhida por capitais locais entre 1890e 1940(Abreu).

Obonde foi oprincipal meiode transporte para as zonas urbanas mais ricas e de classe média. Trens suburbanos servindo asáreas industriais eram destinados aos trabalhadores. Uma nítida segregaçāode classes assim tomou forma durante as últimas décadas doséculo XIX: a zona sul do Rio, com suas belas praias ainda bastante vazias, foiconectada aocentro por umbom meio de transporte público, recebendo diversos melhoramentos urbanos antes de serem transferidas para moradores das elites; $\mathrm{e}$ áreas do norte, muitas delas ex-subúrbios rurais alcançados pelotrem, tornaram-se os lugares da indústria e dos trabalhadores, 


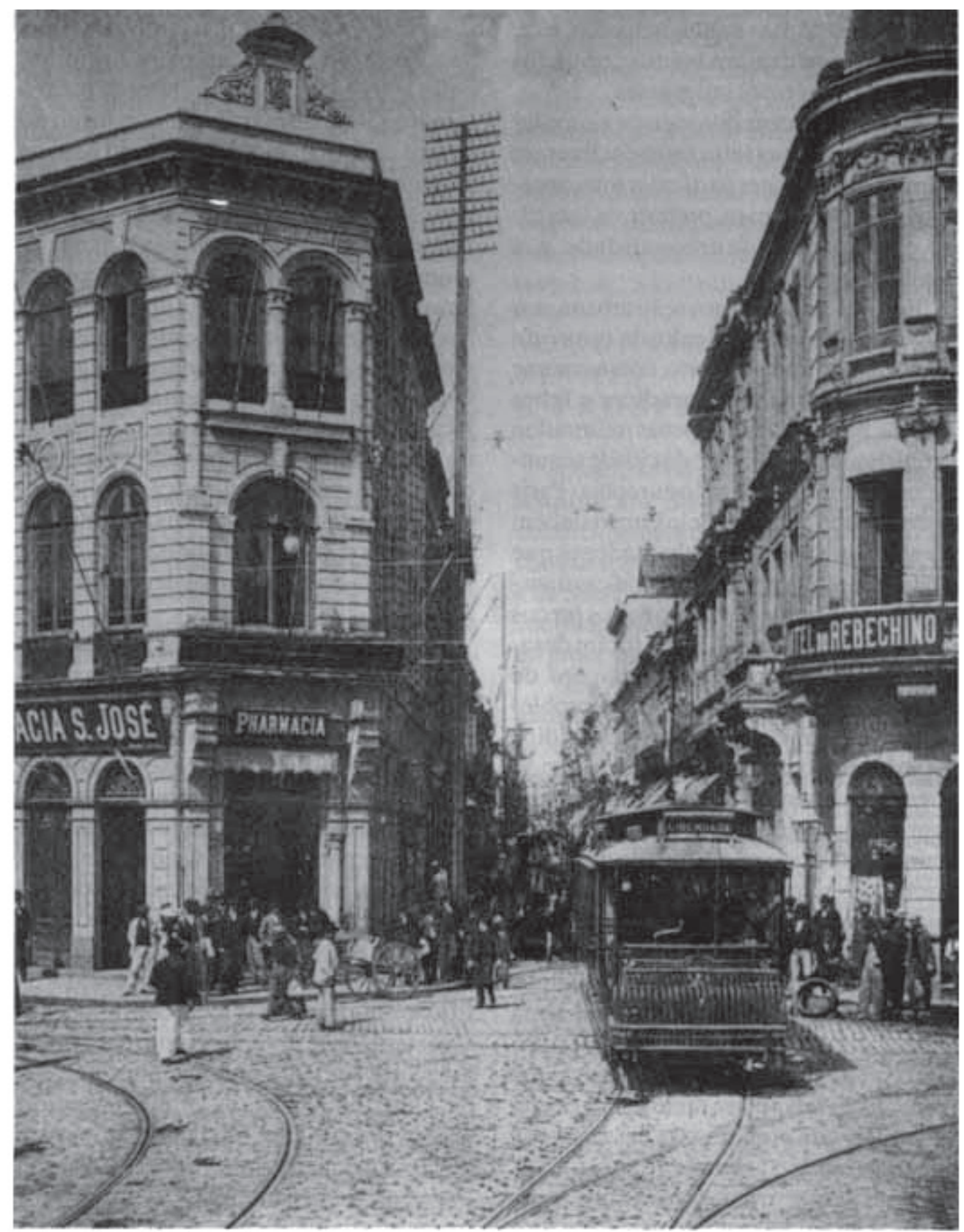

LARGO SAO BENTO, 1902

sendo progressivamente expandidas $\mathrm{cm}$ direção ao centro até tornaram-se completamente conectadas ao mesmo. Em ambos os extremos-norte e sul-, ocapital privado foi responsável pela divisão e vendas das terras, mas não pela instalação da infra-estrutura necessária e pela construção das casas. Essas responsabilidades foram deixadas, respectivamente, para as autoridades federais ou municipais, e para os próprios futuros moradores.

Por heterogêneas que aparentemente fossem, as casas dos bairros mais pobres tinhamalguns padrōes reconheciveis devido à pobreza das técnicas construtivas, à escolha de materiais de construçāo de baixo preço, bem como à força das tradiçōes sobre o seu descnho. Elas eram construídas por etapas, ao longo dos anos, pelas mãos dos próprios moradores ou, de acordo com seus projetos, por artesãos pouco qualificados. A heterogeneidade das casas nas áreas ricas foi maior nessa época, quando toda a família burguesa desejava ter sua villa urbana particular, com características muito singulares. O projeto $\mathrm{e}$ a construçâo das mesmas eram confiados a engenheiros e aos artesãos mais hábeis, geralmente de origem estrangeira (italianos, portugueses ou espanhóis). Padronizaçăo maior só mes- 
mo no correr de casa de aluguel, estas, sim, produzidas por capitais médios, oriundos às vezes dos próprios imigrantes.

Os arranha-céus que vieram a suceder essas villas em seus lotes também tiveram cada um o seu caráter particular mas, apertados num espaço caro, preferiram sacrificar a fantasia à funcionalidade e à lucratividade.

Por outro lado, a renovação urbana, nos primeiros anos desse século, do centro do Rio, incluindoa área doporto, feita em nome da saúde pública para erradicar a febre amarela, na verdade nâo apenas reformulou completamente o coração da cidade segundo padrões de urbanização européia (Paris sendo tomada como modelo), mas também expulsou milhares de trabalhadores que habitavam antigas casas aristocráticas transformadas em cortiços, dando novos preços à terra. Muito poucos dos que foram desalojados receberam novas condiçôes de moradia. Os outros solucionaram oproblema através da invasão de terrenos baldios nos morros vizinhos, năo mais pagando aluguel e mantendo-se próximos de seus lugares de trabalho. Esses eventos promoveram o ecletismo como o estilo do Riode Janeiro dos ricos e, ao mesmo tempo, difundiram as favelas, que existiam antes numa escala absolutamente modesta. Aqueles que puderam pagar preços módicos mudaram-se para áreas suburbanas. Uma vez que as favelas se alastraram do centro para o sul da cidade, no qual os mais ricos moravam, na faixa plana juntoà praia e onde os que serviam alojaram-se nas escarpas ainda sem valor, a segregação social assumiu no Rio nāo só a oposiçăo zona norte versus zona sul, mas também seu curioso padrãovertical, com os pobres tendo vista sobre os refúgios mais íntimos de seus senhores ou patrōes, enraizados em elegantes casas ou apartamentos ao nível do mar.

São Paulo, por seu lado, teve um desenvolvimento imobiliário e de serviço urbano bastante parecido, mas com a constituiçâo gradual de uma estrutura de mercado maior e mais forte, além da menor presença de dinheiro público no seu crescimento inicial. A venda de terra urbana e a construçäo de casas ofereceram oportunidades para o investimento privado, mas freqüentemente elas nāo eram as mais rentáveis. Outra singularidade paulista foi a forte presença de capital estrangeiro no parcelamento das terras que obtiveram os melhores preços.

Com o dinheiro arrecadado em Lon- drese Paris, a São Paulo City Improvements and Freehold Land Company comprou, entre 1905 e 1911, doze milhôes de metros quadrados de terras urbanas em torno do centro de Sảo Paulo. Nelas abriu bairros residenciais adaptando modelos das cidades-jardins britânicas e construindo algumas casas à moda bungalow a fim de demonstrar um estilo de vida. O pacote de bens materiais e imateriais visava atrair a burguesia mais a alta classe média e as vendas continuaram até o final da Segunda Guerra (Bacelli). Representantes da elite local faziam parte da diretoria da imobiliária, desempenhando importantes papéis de consultoria política e jurídica, mediando, portanto, a relaçāo da companhia ou seus acionistas com o Estado brasileiro, com a sua própria classe e com os demais setores sociais.

Mas loteamentos exclusivistas eram negócios já experimentados em São Paulo com grande sucesso por imigrantes aqui radicados. Ospioneiros, Nothmanne Glette, eram alemães que durante as duas últimas décadas doséculo XIXofereceramumnovo bairropara os fazendeiros que se mudavam do interior para a capital. O nome Campos Elísios fazendo alusāo à Grécia mas de fato homenageando a eclética Paris de Haussmann, ao apelar para o deslumbramentoda capital do século, reforçava a identificação da burguesia local com a burguesia externa e seu distanciamento das classes inferiores que iam se aglomerando na cidade. Outro bairro depois também vendido para os ricos do café, Higienópolis, mostra que os loteamentos de elite eram campo bastante atraente para investimento. De novo o nome é altamente sugestivo, denotando tanto uma busca positiva de um local cientificamente resguardado da doença comoo desejo de romper com um passado nāo saudável de proximidade territorial entre as classes. Capitais sobraram ainda para abertura da avenida Paulista e, da mesma forma, abundaram nouveaux riches para povoar seus lotesimensos. Diferentemente dos dois casos anteriores, o nome do topo do espigão constituiu homenagem à tradiçāo e glorificou bairristicamente o contexto regional. Alteando-se acima de todo o espaço aberto à urbe, a burguesia local, embora desejosa da modernizaçāo, não estava disposta a perder lugar de honra no processo.

Também antes de 1930, capitalistas menores já investiam na abertura de loteamentos populares $\mathrm{cm}$ áreas longínquas 
de Sāo Paulo, muito embora os porôes e cortiços próximos ao centro ainda abrigassem ogrossoda populaçăo mais pobre. Esse tipode assentamento periférico dos trabalhadores de baixos salários de fato só veio a se generalizar décadas mais tarde, após o congelamento de aluguéis que restringiu a construção of orta de moradias para renda, e sob a grande expansāo industrial do apósguerra.

Mas é nessa fase inicial que se define opadräo de loteamento rudimentar, que ficou típicoa Sảo Pauloe segregou as classes no espaço. Constituiu-se exclusivamente pela demarcaçáo de lotes $\mathrm{e}$ a abertura de ruas sem preocupações urbanísticas maiores do que a preferência pelo tabuleiro de xadrez, sem cuidados com a preservaçăo dos solos, sem infra-estrutura sanitária, sem investimento e sem qualquer outro serviço público além de alguma acessibilidade por transporte coletivo. As estaçōes de trem tiveram importância para tanto pois, atraindo a indústria, atraíram também a moradia operária.

Provavelmente o lucro desses loteamentos nāo se equiparou ao dos loteamentos "nobres". Indício dissoć o fato de que a São Paulo City Improvements, atrás referida, revendeu terrenos que comprara $\mathrm{cm}$ áreas com perspectivas de ocupaçảo operária(Bacelli). Os loteamentos populares, para aqueles ávidos de deixar os cortiços c capazes de indefectivelmente ir desembolsando o valor das prestaçóes mensais (nessa ćpoca, atingindo 100 meses), representavam não tanto ou năo apenas um lugar só seu, mas a segurança de um rendosoinvestimento. Os profundos lotes desse periodo permitiam o abrigo de famílias extensas, incluindo a parentela e o aluguel de cómodos no quintal. Além disso, $\mathrm{cm}$ poucos anos a expansão cconómica $\mathrm{c}$ demográfica lhes trazia densidade de vizinhos c infra-cstrutura paga primordialmente pelo Estado, valorizando seu pedaço de chăo. Os cmpregados regulares, que resistiam mais facilmente até oúltimo pagamento, lornavam-se sócios do desenvolvimento metropolitano, adeptos do progresso capitalista e fervorosos defensores da propriedade imobiliária. Assim, já antes de 1930. estavam tacitamente assentados alguns dos alicerces da aliança de classes que pacificou proletários e burgueses durante o populismoc a industrializaçáo imperantes após Vargas.

A cidade, em sua investida metropolizante, com suas promessas cumpridas de melhoria para muitos, usou seu corpo no ardil de superaçāo das tensōes sociais e ajudou a garantir o sucesso do modelo de desenvolvimento por substituição de importaçōes. Nāo ć à toa que o acirramentodessas tensōes a que se assiste hoje venha se dando quando se declaram superadas as imagens dodesenvolvimento constante e da "Sāo Paulo que não pode parar".

\section{CONSIDERAÇOES FIN A IS E PROSPECTIVAS}

Busca-se no passado não apenas o entendimento do próprio passado mas condicionantes do presente e do futuro. A comparaçãodos caminhos seculares do Rio e de Sāo Paulo enriquece a percepçăo do seu estágio atual enquanto principais focos do processo de urbanização brasileiro.

Sāo Pauloé hoje a metrópole nacional, não por seu tamanho, que reflete sua capacidade de atração de populaçấo externa e de manutençāoda interna, incorporandoocrescimento vegetativo cos constantes recémchegados. São Paulo é metrópole porque tem hegemonia, ou scja, é o locus, ao mesmotempo, de liderança e de domínio sobre diferentes classes e grupos presentes alhures no território nacional ou até fora delc. São Paulo é metrópole enquanto sede do capital que organiza e drena o trabalho nacional, mesmoque os lucros nela nem sempre se detenham, passando as fronteiras do país.

Esta relaçāo de hegemonia-dependência, algumas vezes sentida como imperialista, foi, nāo obstante, gerada por forças internas, a partir de um quadro local e regional. Nele os posicionamentos burgueses, conscientes quase sempre, muito embora sem previsão de suas conseqüências maiores a longo prazo, trouxeram vantagens socializadas por muitos. A conquista da nação-espaçoe povo-se fez com base num modelo econômico e social que, sem deixar de ter altíssima capacidade de concentração de capitais em seu topo, deu espaço para diferentes níveis de acumulação e consumo. Quer dizer, abrigou uma rica paleta de matizes sociais, cuja base de sustentaçăo geral foiocrescente trabalho livre assalariado. Foi istoque permitiu uma ampla mobilizaçãode sua própria capacidade produtiva, promovendo o crescimento pela auto-alimentaçâo do valor capitalista antes 
de promovê-lo pela expropriaçăo c exploraçảode áreas e grupos externos que depois the foram sendo subordinados.

O que em Sảo Paulo foi complementar, no Riotornou-se essência. Ocapital do Rio foi se esterilizando à medida que a cidade crescia: através do Estado, do governo da República, os setores burgueses sediados no Rio foram fomentados e sustentados por toda a naçăo. Seu dinamismo foi ficando cada vez mais no passado. Seu empobrecimentoveioa galope após a transferência dogoverno federal.

Curiosamente, porém, a unificação da economiabrasileira sobaćgide de SãoPaulo acabou por unir o destino assim como os arrabaldes das duas cidades. Se sua oposição permanece, hoje, ela se dá mais noplano de disputas folclóricas ou dos truques políticos doque node reais divergências de interesse e competiçăo. Se a zona sul do Riotornou-se símbolode lazer, a zona norte integra-se adentrandoo Vale do Paraíba aos emblemas de trabalhovalorizados por SãoPaulo, codesfrute doóciopor paulistas atingiu, pelo litoral, a partir de Santos, a zona sul carioca. As cidades se unem como pólos de uma ampla e densa regiâo urbanizada que incorpora a estratégica área industrializada do Vale do Paraíba, a ponto de a Via Dutra se constituir hoje quase numa avenida de fundo de vale, tal a intensidade de seu trânsito dia e noite. As projeçōes desse focourbano industrial, que há anosjá atingiram Campinas e se projetaram pelo caminhode BeloHorizonte, foram resultadode políticas desenvolvidas nas últimas três décadas, que produziram um Brasil com mais de $70 \%$ de urbanização, quando ao final do periodo aqui tratado esse índice nâo atingia $30 \%$

Mas nessas mesmas últimas décadas, São Paulo foi se constituindo como cabeça de ponte de investimentos, na produção ou nos serviços, a que sua burguesia se associa mascujas opçöes já não controla. Com isso e com a globalização da cconomia que atrai para fora capitais aqui criados, a metrópole vê em perigo a sua própria capacidade de comandar e atrair. A crise atual empobreceu fortemente a populaçâo paulistana que começa a manifestar incerteza e descontentamento com as promessas de prosperidades sempre adiadas.

Oexemplo do Rio, que no auge do seu brilhoperdeu suportes, é um alertaque, atingindo a metrópole brasileira, atinge a naçẩo.

\section{Bibliografia}

\footnotetext{
ABREU, Maurício. Evoluşao Urbana doRiode Janeiro. Rio de Janciro, Iplanrio-Zahar, 1987.

BACELLL, Ronci. A Cia. City e o Primeiro Bairro Jardim de Sáo Paulo. Faculdade de Filosofia, Letras c Ciéncias Humanas da Universidade de Sảo Paulo, 1982.

BETHELL, L. c CARVAL.HO, J. M. de. “1822-1930”, in L. Bethell (cd.), Brazil, Empire and Republic, 1822-1930. Cambridge University Press, 1989, pp. 45-112.

CANO, Wilson. Origens da Concentração Industrial em São Paulo, Sảo Paulo, T. A. Queiroz, 1981.

CARVALHO, J. M. Os Bestializados: o Rio de Janeiro e a República que Não Foi. Sáo Paulo, Companhia das Letras, 1987.

CEPAL - Statistical Yearbook for Latin America and the Caribbean, 1959 cdition. Santiago, United Nations, 1990.

DEAN, Warren. The Industrialization of Sào Paulo, 1880-1945. Austin, Un. of Texas Press, 1969.

DEAN, Warren. "Economy", in L. Bethel (cd.), BrazilEmpireand Republic, 1922-1930. Cambridge University Press, 1989. pp. 217-56.

FAUSTO, B. "Brazil: Social and Political Structure, 1889-1930", in L. Bethell (ed.). The Cambridge History of Latin America, vol. V. 1870-1930. Cambridge Un. Press, 1986, pp. 779-830.

FIBGE - Anuário Estatistico do Brasil, 1987. Rio de Janciro, Fibgc, 1988.

FRANCO, M. S. de C. Homens Livres na Ordem Escraø crata. Sảo Paulo, Universidade de Sáo Paulo, 1969.

FRITSCH, Wilston. "Apogeu e Crise na Primeira República”, in M. P. Abreu (ed.), AOrderndo Progresso: Cem Anos de Politica Econômica Republicana, 1859-1989. Rio de Janciro. Editora Campus, 1990.

FURTADO, Celso, FormaçãoEconômica do Brasil. Rio de Janciro, Fundo de Cultura, 1958. GEIGER, Pedro P. Evoluçãoda Rede Urbana Brasileira. Rio đe Janciro, Centro Brasileiro de Pesquisas Educacionais, 1963.
} 
GranZIERA, Rui G. A Guerra do Paraguai e Capitalismo no Brasil. São Paulo, Hucitec-Unicamp. 1979.

GREENHILL, Roberto. "The Brazilian Coffec Trade", in D. C. M. Platt (ed.), Business Imperialism, 1840-1930. An inguiry based on British experience in Latin America. Oxford, Clarendon Press, 1977. pp. 198-230.

HARDOY, Jorge E. e LANGDON, M. E. “Analisis Estatístico Preliminar de la Urbanización de América Latina entre 1850 y 1930", in Revista Paraguaya de Sociologia, 42-43, 1978, pp. 146-8. Citado por Scobic.

LEOPOLDI, M. A.P. “Crescimento Industrial, Políticas Govemamentais e Organização da Burguesia: o Rio de Janciro de 1844 a 1914", in Revista Rio de Janeiro, n²3, 1986, pp. 53-73.

LEVY, M. B. e SAES, F. A. M. "Foreign Loans, Debt and Dependency: Brazil 1850-1913", 10th International Economic History Congress Leuven, 1989 e 1990.

LEVY, M. B. História da Bolsa de Valores do Rio de Janeiro. Rio de Janeiro, Instituto Brasileiro de Mereado de Capitais, 1987.

LOBO, Eulália M. L. História do Rio de Janeiro: do Capital Comercial ao Capital Industrial e Financeiro. 2 vol. Rio de Janeiro, Instituto Brasileiro de Mercado de Capitais, 1978.

LOVE, Joseph. São Paulo in the Brazilian Federation, 1889-1973. Stanford Univ. Press, 1980.

MANCHESTER, Alan. The British Preeminence in Brazil, its Raise and Decline. Durham, Duke Un. Press, 1933.

MATTON Jr., Robert. "Railroads, Coffec and Growth of Big Business in São Paulo, Brazil", in Hispanic American Historic Review, v. 57, $\mathrm{n}^{*} 2,1977$.

MERRICK, T. e GRHAM, D. Population and Economic Development in Brazil, 1800 to the present. John Hopkins Un. Press, 1979.

MONBEIG, Pierre. La Croisance de la Ville de SãoPaulo, Grenoble, Institute de Geographie Alpine, 1953.

- Pioners et Planteurs de Sáo Paulo. Paris, Armand Colin, 1952.

PECHMAN, S. e FRITSCH, L. "A Reforma Urbana e seu Avesso: Algumas Considerações a Propósito da Modernização do Distrito Federal", in Revista Brasileira de História, vol. 5, n²5. 8-9, set./1984-abril/ 1985, pp. 139-96.

PETRONE, M. T. S. O Barâodelguape, São Paulo, Cia. Editora Nacional.

PRADO Jt., C. "O Fator Geográfico na Formaçấo da Cidade de São Paulo", in Evolução Política do Brasil coutros Ensaios. Sâo Paulo, Brasiliense (c. 1933, Ed. Martins).

\footnotetext{
- Formação do Brasil Contemporâneo. Sảo Paulo, Brasiliense (c. 1942, Ed. Martins).
}

- História Económica do Brasil. São Paulo, Brasilicnse, 1945.

RATTNER, H. Industrialização e Concentração Econômica em São Paulo. São Paulo, Fund. Getúlio Vargas, 1972.

RIBEIRO, L. C. Q. "The Constitution of Real Estatc Capital and the Production of Built-up Space in Rio de Janeiro, 1870-1930". International Journal of Urban and Regional Research, 13(1) 1989, pp. 47-67.

SCOBIE, J. R. "The Growth of Citics", in L. Bethell (org.), Latin America: Economy and Society, 1870-1930. Cambridge Un. Press, 1989, pp. 149-81.

SILVA, Sergio. Expansão Cafecira e Origens da Induistria no Brasil. Sảo Paulo, Alfa-Ômega, 1976. SIMONSEN, Roberto. História Económica do Brasil, 1500-1820. Sảo Paulo, Cia. Editora Nacional. 1957.

. Evoluçâo Industrial do Brasil e Outros Estudos. Sáo Paulo, Cia. Editora Nacional, 1968. SINGER, Paul. Desenvolvimento Econômico e Evolução Urbana. São Paulo, Cia. Editora Nacional, 1968.

SOARES, L_C. “A Manufatura na Sociedade Escravista: o Surto Manufatureiro no Rio de Janciroc Circunvizinhanças, 1840-1870", in La Pre-Industrialisationdu Brésil. Paris, Editions CNRS, 1984. SOUZA MARTINS, J. O Conde Matarazzo, Empresário e Empresa. Sảo Paulo, Editora Hucitec, 1973. STEIN, Stanley. The Brazilian Cotton Manufacturing: Textil Enterprise in an Underdeveloped Area, 1850.1950. Harvard Univ. Press, 1957.

- Vassouras: a Brazilian Coffee Country. Harvard Univ. Press, 1957 (tradução para o português cditada $\mathrm{cm}$ 1961).

SZMRECSANYI, M. I. Produção, Apropriação e Organização do Essaç̧o na Economia Cafecira: Contrastes entre o Vale do Paraiba e o Oeste Paulista, 1800-I930. São Paulo, FAU-USP. Sinopses, II (5) jun. $/ 1984$, pp. 189-257.

. "Contribuição ao Estudo da Urbanizaçâo no Brasil", in D'Incao M. A. (cd.), História e Ideal: Ensaios sobre Caio PradoJr. São Paulo, Brasiliense-Secretaria da Cultura-ESP-Unesp, 1989. pp. 369-77.

SZMRECSANYI, T. "Foreign Capital in the Brazilian Industrialization Before 1930". Paper apresentado no St. Antony's College, Oxford, 1990.

TOLEDO, B. L. São Paulo, Trếs Cidades em um Século. São Paulo, Nobel, 1979.

VIOTTI DA COSTA, E. DaSenzala à Colônia. São Paulo, Dífusão Européia do Livro, 1966.

. "Brazil: the Age of Reform, 1870-1889", in L. Bethell (ed.), The Cambridge History of

LatinAmerican, pp. 725.78.

WEID, E. von der c BASTOS, A. M. R. O Fio da Meada: Estratégia de Expansão de uma Indústria

Têxatil. Rio de Janeiro, Fundaçấo Casa de Rui Barbosa-Confederaçẩo Nacional da Indústria, 1986. 